\title{
Childhood Tuberculosis in a Reference Children's Hospital After Admission of Refugees
}

\section{Mültecilerin Kabulünden Sonra Bir Referans Çocuk Hastanesinde Çocukluk Çağı Tüberkülozu}

\author{
Özge Metin Akcan'1, Ayşe Kaman² \\ ${ }^{1}$ Necmettin Erbakan Univercity School of Medicine, Division of Pediatric Infectious Diseases Konya, Turkey \\ 2Dr. Sami Ulus Maternity and Children's Research and Training Hospital, Division of Pediatric Infectious Diseases, Ankara, Turkey
}

\begin{abstract}
Aim: We aimed to evaluate epidemiologic, clinical, laboratory, microbiologic features, treatment and outcomes of pediatric tuberculosis (TB) patients also to draw attention to immigrant patients.

Material and Method: We retrospectively conducted the medical records of children below 18 years of age with TB between January 2015 and September 2016.

Results: A total of 20 TB patients (35\% were Syrian refugees, total $65 \%$ female) with a median age of $135.5 \pm 52.6$ months were evaluated. Fourteen (70\%) patients were adolescent. The history of contact with an active TB disease patient was found in seven (35\%) patients. Four (20\%) patients had no complaint at admission whereas the most common symptom was prolonged cough $>2$ weeks. Fifteen (75\%) patients had a Bacillus Calmette-Guérin scar on the left shoulder. A total of $16(80 \%)$ patients had a positive tuberculin skin test (TST) result. Microbiological confirmation was provided in four (20\%) patients totally. The most common chest $\mathrm{X}$-ray findings on admission were hilar lymphadenopathy. Ten (50\%) patients had normal chest X-ray and were diagosed with abnormal thorax tomography findings. All of the patients were treated succesfully except one Syrian patients with miliary TB who died.

Conclusion: Microbiological confirmation of childhood TB may be absent and the diagnosis can be confirmed in the light of contact history, positive TST reaction, compatible symtomps and radiological evidence. Particular attention might be paid to Syrian refugees, taking into epidemiological characteristics of TB disease and the density of immigrants in the place we live in.
\end{abstract}

Keywords: Children, tuberculosis, Syrian refugees
Öz

Amaç: Pediatrik tüberküloz (TB) hastalarının epidemiyolojik, klinik, laboratuvar, mikrobiyolojik özellikleri, tedavisi ve sonuçlarını değerlendirerek göçmen hastalara dikkat çekmeyi amaçladık.

Gereç ve Yöntem: Ocak 2015-Eylül 2016 tarihleri arasında 18 yaş altı TB'li çocukların tıbbi kayıtlarını geriye dönük olarak incelendi.

Bulgular: Yaş ortalaması 135,5 \pm 52,6 ay olan 13'ü (\%65) kadın ve 7'si (\%35) erkek olmak üzere toplam 20 TB hastası (\%35'i Suriyeli mülteci) değerlendirildi. On dört (\%70) hasta ergendi. Yedi (\%35) hastanın aktif bir TB hastası ile temas öyküsü mevcuttu. Dört (\%20) hastanın başvuru anında hiçbir şikayeti yokken en sık görülen semptom 2 haftadan uzun süren inatçı öksürüktü. On beş (\%75) hastanın Bacillus Calmette-Guérin skarı vardı. Onaltı (\%80) hasta tüberkülin deri testi (TDT) pozitifti. Toplam dört (\%20) hastada mikrobiyolojik doğrulama sağlandı. Başvuru anında en sık görülen akciğer grafisi bulgusu hiler lenfadenopatiydi. On (\%50) hastanın akciğer grafisi normaldi ve anormal toraks tomografi bulguları ile tanı konulmuştu. Yalnızca miliyer tüberküloz tanısı ile izlenen bir hastada tedavi başarısızlığı olup hasta kaybedilmişti.

Sonuç: Tüberküloz önemli bir bulaşıcı hastalık olup çocuklarda mikrobiyolojik doğrulama her zaman olmayabilir. Çocukluk çağı TB tanısı, temas öyküsü, pozitif TDT reaksiyonu, uyumlu spesifik olmayan semptomlar ve radyolojik bulgularla doğrulanabilir. Tüberküloz hastalığının epidemiyolojik özellikleri ve yaşadığımız yerdeki göçmen yoğunluğu dikkate alınarak Suriyeli mültecilere özel dikkat gösterilebilir.

Anahtar Sözcükler: Çocuklar, tüberküloz, Suriyeli mülteciler

Corresponding (illetişim): Ayşe Kaman, Dr. Sami Ulus Maternity and Children's Research and Training Hospital Babür street Number:44 (06080) Altındağ Ankara, Turkey

E-mail (E-posta): ayse092003@yahoo.com

Received (Geliş Tarihi): 29.12.2020 Accepted (Kabul Tarihi): 24.01.2021 


\section{INTRODUCTION}

Tuberculosis (TB) is an important public health problem around the world which have been known as a communicable disease since the early era of humanity. It remains one of the top ten causes of death in all ages worldwide and the leading cause of death from a single infectious agent. ${ }^{[1,2]}$ It is was reported that by World Health Organization (WHO) in the 2020 annual global TB report, the TB incidence rate is falling slowly in recent years. The annual incidence of TB in 2019 has been reported as 10 million (range, 8.9-11.0 million) and the rate of children (aged $<15$ years) was $12 \%$. Most of the TB cases were reported from South-East Asia, Africa and the Western Pacific respectively. also lower ratios were determined in the Eastern Mediterranean, America and Europe. ${ }^{[3]}$ In Turkey, the estimated incidence and mortality rate of TB in 2019 was 17 and 0.53 per 100.000 population, respectively. ${ }^{[4]}$ After the Syrian civil war, over five million refugees, of whom more than three million have fled to Turkey to seek safety have been forced. Before the civil war in Syrian Arab Republic, the incidence of TB have been in the trend of decreasing with 21 cases per 100000 population. According to Geneva Convention Relating to the Status of Refugees, Syrian refugees are provided to access to healthcare and treatment free of charge, access to education for their children. ${ }^{[5]}$ It is well known that TB is a communicable disease that may be affected by socioeconomic conditions including civil wars, disasters, poor nutrition, lack of food and poverty. Syrian refugees may be at risk of contracting TB because of overcrowding within the temporary shelters, stres an other determinants that can disrupt to acces to health services. ${ }^{[5,6]}$ Given the unclear non-specific syptoms, low bacillus load in respiratory samples and the low rate of microbiologic evidence, the rates of definitive diagnosis in childhood TB cases are very low. ${ }^{[1]}$ In this study, we aimed to evaluate epidemiologic, clinical, laboratory, microbiologic features, treatment and outcomes of pediatric TB patients. We also aimed to describe the characteristics of immigrant patients due to the risk of uncontrolled migration to Turkey during this period.

\section{MATERIAL AND METHOD}

We retrospectively analyzed the medical records of children under 18 years of age with TB between January 2015 and September 2016. The study protocol was approved by the Ethics Committee of the Necmettin Erbakan Univercity School of Medicine with the decision number of 2020/2871. Data regarding age, sex, contact history with an index case, clinical features, the results of tuberculin skin test (TST), microbiological and radiological findings were evaluated retrospectively. The characteristics of immigrant patients were evaluated separately. The diagnosis of TB was performed according to the guidelines of the Turkish Ministry of Health ${ }^{[7]}$ in the light of symptoms, history of contact, positivity of TST and presence of appropriate radiologic findings. The positive TST results were defined as indurations of $\geq 15 \mathrm{~mm}, \geq 10 \mathrm{~mm}$ and $\geq 5$ $\mathrm{mm}$ for Bacillus Calmette-Guérin (BCG) vaccinated (BCG scar presence on the left shoulder), non-vaccinated and immunosuppressive cases respectively. Complete blood cell findings were defined as follows thrombocytopenia, a platelet count $<150.000 / \mathrm{mm}^{3}$, leukopenia and anemia, a level that lower than age-determined references, leukocytosis, a leukocyte count $>15000 / \mathrm{mm}^{3}{ }^{3[8]}$ Erythrocyte sedimentation rate (ESR) and C-reactive protein (CRP) were defined as elevated in patients who had $>20 \mathrm{~mm} /$ hour and $>15 \mathrm{mg} / \mathrm{L}$ respectively. ${ }^{[9]}$ All of the patients were underwent Human Immunodeficiency Virus (HIV) screening by antiHIV serological test. All clinical samples were studied for Mycobacterium tuberculosis culture, Acid-fast bacillus (AFB) staining and mycobacteria polymerase chain reaction (PCR). Chest X-rays and thorax computed tomography (CT) of all patients were evaluated by a experienced radiologist. The patients were entitled as pulmonary or extrapulmonary TB. Standard anti-TB treatment was prescribed as four drugs [Isoniazid (INH), rifampicin, pyrazinamide, and ethambutol] or three drugs (INH, rifampicin and pyrazinamide) through the first two months followed by two drugs (INH and rifampicin). All of the patients were monitored for drug side effects and disease control monthly. We started contact tracing for all patients in their family and other intimate contacts to identify new cases.The Statistical Package for the Social Sciences (SPSS) 15.0 version was used for the statistical analysis. Numerical variables were summarized as mean \pm standard deviation or median (minimum-maximum) while quantitative variables as count and percent.

\section{RESULTS}

A total of 20 patients (35\% were Syrian refugees) including $13(65 \%)$ female and 7 (35\%) male diagnosed with TB with a median age of $135.5 \pm 52.6$ months were evaluated in this study. Demographic, epidemiological and microbiological features of patients were showed in Table 1. Characteristics of Syrian refugees patients were presented in Table 2. Fourteen $(70 \%)$ patients were diagnosed during adolescence. A history of contact with an active TB disease patient was found in seven (35\%) patients. A total of seven (35\%) patients were diagnosed during contact tracing of an index case. Sixteen of the patients were presented with at least one symptom compatible with TB whereas four patients were asymptomatic at admission. The most common clinical symptoms were prolonged persistent cough longer than 2 weeks in seven (35\%) patients, following with fever in five $(25 \%)$, sputum discharge in five $(25 \%)$, fatigue in five $(25 \%)$, erythema nodosum in four $(20 \%)$, night sweats in three $(15 \%)$, weight loss in three $(15 \%)$ and headache in one $(5 \%)$ patient. Fifteen (75\%) patients had a BCG scar on the left shoulder. A total of $16(80 \%)$ patients had a TST 
measurement $\geq 15 \mathrm{~mm}$ (six patients had $\geq 20 \mathrm{~mm}$ ). Complete blood count parameters were normal in all patients except one each patient with anemia and leukocytosis. Elevated CRP and ESH were detected in six (30\%) and nine (45\%) patients respectively. All of the patients had negatif antiHIV serology. Clinical samples were inoculated for $M$. tuberculosis culture from nine (45\%) patients and three of them were yielded positive. Microbiological confirmation was provided in four (20\%) patients totally. M. tuberculosis PCR test was positive in two of the patients. Acid-fast bacillus staining was positive in $2(10 \%)$ patients. The most common chest X-ray findings on admission were hilar lymphadenopathy in $4(20 \%)$ patients, followed by consolidation in $3(15 \%)$, reticulonodular infiltration in 2 $(10 \%)$, cavitary lesion, pleural effusion, atelectasis, nodule in one patient each. Ten (50\%) patients who had normal chest radiography were diagosed with abnormal CT findings. The most common thorax CT findings were hilar and mediastinal lymphadenopathy in 7 (35\%) and 6 (30\%)

\begin{tabular}{|c|c|c|c|}
\hline & Total $(n=20)$ & Syrian $(n=7)$ & $\begin{array}{c}\text { Turkısh citizen } \\
(n=13)\end{array}$ \\
\hline $\begin{array}{l}\text { Mean Age } \pm S D \\
\text { (minimum-maximum) }\end{array}$ & $\begin{array}{c}135.5 \pm 52.6 \\
\text { months } \\
\text { (4-192 months) }\end{array}$ & $\begin{array}{c}100.5 \pm 70.7 \\
\text { months } \\
\text { (4-172 months) }\end{array}$ & $\begin{array}{c}154.3 \pm 27.9 \\
\text { months } \\
\text { (102-192 months) }\end{array}$ \\
\hline Gender, (n) (F/M) & $13 / 7$ & $6 / 1$ & $7 / 6$ \\
\hline $\begin{array}{l}\text { Diagnosis during } \\
\text { adolesence, } n(\%)\end{array}$ & $14(70 \%)$ & $3(42.8 \%)$ & $11(84.6 \%)$ \\
\hline $\begin{array}{l}\text { Presence of BCG scar, } \\
n(\%)\end{array}$ & $15(75 \%)$ & $5(71.4 \%)$ & $10(76.9 \%)$ \\
\hline $\begin{array}{l}\text { Contact with active TB } \\
\text { patient, } \mathrm{n}(\%)\end{array}$ & $7(35 \%)$ & $4(35 \%)$ & $3(35 \%)$ \\
\hline $\mathrm{TST} \geq 15 \mathrm{~mm}, \mathrm{n}(\%)$ & $16(80 \%)$ & $6(85.7 \%)$ & $10(76.9 \%)$ \\
\hline $\begin{array}{l}\text { M. tuberculosis culture } \\
\text { Positive/Total (n) }\end{array}$ & $3 / 9$ & $1 / 4$ & $2 / 5$ \\
\hline $\begin{array}{l}\text { M. tuberculosis PCR } \\
\text { Positive/Total (n) }\end{array}$ & $2 / 9$ & $1 / 4$ & $1 / 5$ \\
\hline $\begin{array}{l}\text { AFP staining positivity } \\
\text { Positive/ Total (n) }\end{array}$ & $2 / 9$ & $1 / 4$ & $1 / 5$ \\
\hline
\end{tabular}

patients respectively. The thorax CT findings of patients are summarized in Table 3. A 14 years old Syrian patient who had tuberculoma on cranial imaging and pulmonary involvement was diagnosed as miliary TB. Lumbar puncture was performed in a patient younger than 1 year old, resulting as no central nervous system involvement. Eight (40\%) of the patients were hospitalized before the definitive diagnosis made. Standard anti-TB protocol with three drugs (INH, rifampicin and pyrazinamide) regimen was prescribed in $15(75 \%)$ patients and with four drugs regimen in $5(25 \%)$ patients through the first two months followed by two drugs (INH and rifampicin). An additional steroid treatment was implemented in one patient diagnosed with miliary TB. Pyrazinamide-induced hyperuricemia was developed in seven (35\%) patients during treatment course. Moreover one (5\%) patient experienced eosinophilia during antiTB treatment. All of the patients were treated succesfully except one Syrian patients with miliary TB who died.

Table 3. Chest CT Findings of Pulmonary TB Patients

\begin{tabular}{lll} 
Signs & $\mathbf{n}$ & $\%$ \\
\hline Hilar LAP & 7 & 35 \\
Mediastinal LAP & 6 & 30 \\
Nodule & 5 & 25 \\
Branching tree view & 3 & 15 \\
Effusion & 3 & 15 \\
Cavitation & 3 & 15 \\
Ghon complex & 2 & 10 \\
Fibrotic changes & 1 & 5 \\
Atelectasis & 1 & 5 \\
Consolidation & 1 & 5 \\
Miliary pattern & 1 & 5 \\
\hline LAP: Lymphadenopathy & & \\
\hline
\end{tabular}

Table 2. Characteristics of Syrian refugees patients

\begin{tabular}{|c|c|c|c|c|c|c|c|c|}
\hline $\begin{array}{l}\text { Patient } \\
\text { no }\end{array}$ & $\begin{array}{c}\text { Age } \\
\text { (months) }\end{array}$ & Clinic positivity & $\begin{array}{c}\text { New case in } \\
\text { family contact } \\
\text { tracing }\end{array}$ & BCG scar & $\underset{(\mathbf{m m})}{\mathrm{TST}}$ & $\begin{array}{l}\text { Microbiological } \\
\text { diagnosis }\end{array}$ & Chest X-ray & Thorax CT \\
\hline 1 & 43 & Asymptomatic & No & Absent & 20 & Negative & Normal & Mediastinal LAP \\
\hline 2 & 131 & Yes & No & Present & 20 & Positive & Normal & Hilar LAP,fibrotic changes \\
\hline 3 & 4 & Asymptomatic & Yes & Present & 13 & Negative & Normal & Pleural based nodule \\
\hline 4 & 35 & Asymptomatic & Yes & Absent & 18 & Negative & Normal & Mediastinal, hilar LAP \\
\hline 5 & 172 & Yes & Yes & & 17 & Positive & Cavitation & $\begin{array}{l}\text { Cavitation, } \\
\text { branching tree view }\end{array}$ \\
\hline 6 & 151 & Asymptomatic & Yes & Absent & 15 & Negative & Normal & Ghon complex \\
\hline 7 & 168 & Yes & Yes & Present & 15 & Positive & $\begin{array}{l}\text { Reticulonoduler } \\
\text { infiltrasion }\end{array}$ & $\begin{array}{l}\text { Mediastinal LAP, nodule, branching } \\
\text { tree view, miliary images }\end{array}$ \\
\hline
\end{tabular}




\section{DISCUSSION}

It was reported that in 2019 National Turkey TB Report, the total TB patients were counted as 12.046 in 2017 and $4.6 \%$ of the patients were in the $0-14$ age group whereas $15.4 \%$ of them were in 15-24 age group. ${ }^{[4]}$ The risk for $M$. tuberculosis disease in childhood is highest younger than 2 years of age and during early adolescence. Disease risk is lower between 5-15 years of age, often known as "favored age for childhood TB".[2,10] Because of most children with TB have been infected from adults in their close contacts, childhood TB tends to be more common in the areas that adult TB could not be controlled. ${ }^{[2,11]}$ For this reason the presence of contact history with an adult patient infected with $M$. tuberculosis is the milestone for keeping in mind and further investigation of TB in children. In a recent study from Turkey including ten years experience of a tertiary care university hospital, a total of 93 patients (53\% male) ranged 3-205.2 months were included. Thirty-nine percent of the patients were over 10 years of age and five patients (8.1\% of those with known BCG vaccination status) had no BCG scar on the left upper arm. Also $29 \%$ of the patients had a history for contact with an adult index case. ${ }^{[1]}$ In an another multicenter study from Turkey, 539 (50.8\% male) children with TB aged 10 days- 17 years (almost equal distribution in all age groups) from 16 different centers were evaluated over a 12 year period. The authors showed that contact with an index case was present in $39.8 \%$ of the patients and they concluded household contact screening techniques act very important role. ${ }^{[12]}$ In a cross-sectional study from Ethiopia, which presents as the seventh highest TB burden country worldwide, a total of 384 children (51\% male) with a mean age of $8.56 \pm 3.91$ years which were evaluated. The most of the patients (39\%) were in 6-10 years of age group, while $34.11 \%$ were in adolencent age group. It was indicated that $39.8 \%$ of the patients had a history for contact with active TB patients. ${ }^{[13]}$ Similar to the mentioned children studies we detected a contact history with an index case in about one third of the patients. Furthermore we detected a female gender predominance with a ratio of 1.8:1 and most of the children in this study were diagnosed during adolescence.

The symptoms and physical signs of childhood pulmonary TB are usually not distinctive and not compatible with the degree of radiographic involvement even may be asymptomatic in many children. The most common reported symptoms are prolonged cough, fatigue and fever in many studies with high sensitivity and specificity for pulmonary TB. ${ }^{[2,11]}$ In a study from an endemic area for TB, it was reported that all of the children had cough for more than three weeks, $61.46 \%$ of had fever, $59.64 \%$ of had loss of appetite and $43.75 \%$ of had weight loss. ${ }^{[13]}$ In a large study conducted in İstanbul, it was shown that the most common symptoms were cough more than 2 weeks and fever while $8 \%$ of the patients were asymptomatic and had no abnormal physical examination finding. ${ }^{[14]}$ In an another study from a tertiary care reference hospital, 144 children with active TB were included, the most common clinical complaint was cough, one-third of patients had at least one symptom while $16 \%$ of patients were asymptomatic. [11] The most common sypmtoms were cough, fever and fatigue respectively similar to previous studies. In this study including children with active pulmonary TB, $20 \%$ of children had no complaint, suggesting that absence of symptoms is not reliable to exclude the pediatric TB diagnosis.

In addition to compatible clinical and/or physical examination findings, close contact history with an active TB patient, a positive TST or interferon-gamma release assay and suggestive findings on a chest radiography might aid to diagnosis of TB in children. ${ }^{[2,11,14]}$ Although the TST and/or IGRA does not provide information for having active TB disease, they are valuable for showing whether the case has been infected with the M. tuberculosis or not. ${ }^{[2,15]}$ Evaluation of TST results in $B C G$ vaccinated children is a diagnostic dilemma because of cross reaction with BCG antigens. Nonetheless TST continues to be the most valuable, simple and inexpensive method to diagnose new cases, the prevelance and annual risk of TB in a country. It has been reported that the TST sensitivity for culture positive TB patients vary between 75-90\%. ${ }^{[15]}$ Furthermore definite diagnosis rates of TB in childhood is low due to low bacillus load and insufficiency to ensure appropiate sputum specimens for diagnosis. ${ }^{[2,11]}$ In a multicenter pediatric study including 20 years experience, TST was positive in $55.3 \%$ of the patients. Acid-fast bacillus staining, M. tuberculosis PCR and culure for $M$. tuberculosis complex were positive in $24.6 \%$, $8 \%$ and $13.9 \%$ of the patients respectively. ${ }^{[12]}$ In a study from Brasil involving 145 TB patients $(60.7 \%$ had pulmonary TB and $39.3 \%$ had extrapulmonary TB) with a median age of 7 years, TST was applied in 83 patients. Microscopy, culture and TST were positive in $35.7 \%, 65.8 \%$ and $72.3 \%$ of the patients respectively. ${ }^{[16]}$ In a study from our country, 250 children (162 patients had only pulmonary disease, 49 patients had only extrapulmonary disease, 39 patients had both pulmonary and extrapulmonary disease) with TB were enrolled. It was found that, TST was performed in 210 cases and was positive in $53.3 \%$ of them. A microbiological evaluation (direct microscopy and/or culture) was available in $48.8 \%$ of the patients. It was recorded that AFB staining and $M$. tuberculosis culture were positive in $13.1 \%$ and $18.7 \%$, respectively. ${ }^{[14]}$ It is known that bacteriological confirmation of TB is not always possible in children because of the low bacillus rate in the respiratory tract of children and the inability to spit enough sputum samples to make a sufficient microbiological confirmation at the time of the medical visit. Gastric lavage, a relatively invasive procedure, might be an alternative for children but it should be kept in mind that this procedure requires hospitalization. ${ }^{[14,16]}$ In the present study a positive TST measurement was observed for a rate $80 \%$ which is slightly higher than previous reports. Clinical specimen could only be obtained from half of the patients for microbiological evaluation because of the low hospitalization chance of the patients. In seven patients who had a history for contact with an active TB patient, diagnosis was made according to compatible clinical, TST and radiological findings and treatment was prescribed according 
to the culture susceptibility of index cases. Microbiological confirmation was achieved in one fifth of total patients.

The most common radiographic findings in childhood TB were reported as consolidation, hilar and/or mediastinal LAP and pleural effusion, following with at a lower rates of paratracheal LAP, miliary images, Ghon complex. Unfortunately the sensitivity and specificity of chest X-ray are low for the diagnosis of TB in children. ${ }^{[11]}$ A study from Taiwan that aimed to investigate if thoracic CT will demonstrate compatible lung lesions for TB when chest $X$-ray is unremarkable included 26 patients. In half of the TB patients chest $X$-ray was normal despite the presence of LAP and/or nodule on $\mathrm{CT}^{\left[{ }^{[17]}\right.}$ In an another work, chest $\mathrm{CT}$ findings in immunocompetent children under 36 months of age with pulmonary TB were described. All of the patients with normal chest X-ray had lymph node enlargement and consolidations. In the half of the patients cavitation was present. ${ }^{[18]}$ Half of our patients had normal chest $X$-ray and diagnosed with chest $\mathrm{CT}$ findings. The most common radiological findings were hilar and mediastinal lymphadenopathy and nodule formation similar to previous reports.

It is well known that TB is a socioeconomic disease. In Turkey, TB screening programme and treatment are free for Turkısh citizen and refugees who had identity card. Especially temporary shelters are high risk for transmission of TB. It was noted that, 26213 refugees were secreened for having TB in temporary shelters and 108 cases with active TB were diagnosed. ${ }^{[5,6]}$ Before the migration of Syrian refugees, there was no Syrian born active TB case in 2011 while the ratio of the patients who were born outside of Turkey to the all patients with TB was $1.3 \%$. In recent years the number of Syrian TB cases was increased, and in 2018; 595 cases of Syrian TB was noted. The proportion of total TB cases born in a foreign country was reported as $10.8 \%$ whereas the Syrian cases ratio was $5 \%$. It was declared that, despite the increase in the proportion of Syrian patients, no significant increase has been detected in total TB cases for Turkey. ${ }^{[4,5]}$ It is estimated that Syrian refugees are at higher risk for contracting TB because of unfavorable living conditions. ${ }^{[5,6]}$ In a report from Hatay TB Dispensary (a city in Turkey which is neighboured to Syria), where a large number of Syrian refugees have migrated, it was reported that $68.7 \%$ of Syrian refugees were in the $0-5$ age group and the results of this study was compatible with another studies that demonstrated the age structure of Syrian refugees seems to be young. Also more positive TST results developed in refugees in the 6-18 age group and it was concluded that the annual risk of TB infection was higher in Syrian refugees in this age group compared to Turks. ${ }^{[15,20]}$ In a study from Jordan that aimed TB contact-tracing among Syrian refugees, it was found that a high prevalance of active TB and latent TB in contacts of pulmonary TB patients. ${ }^{[19]}$ In the present study the proportion of Syrian TB cases was $35 \%$ of all the patients and it was higher than Turkısh National datas. In addition to this, the mean age of Syrian refugees were younger than Turkısh citizens. This might be as a result of that children are at higher risk for development of TB infection. Also younger age of Syrian population might be explained by the overcrowding, stress, food deficiency and other determinants which may increase the incidence of an infectious disease in this population escpecially affects negatively in childhood. In addition to all of this information, it is known that careful contact tracing enables to diagnose at young ages.

\section{CONLUSION}

TB is an important contagious disease and physicians should take care of TB especially during adolescence. In children microbiological confirmation may be absent. Diagnosis of childhood TB can be confirmed in the light of history contact with an active case, positive TST reaction, compatible nonspecific symptoms particularly prolonged cough and radiological evidence. Physicians should take in mind the regional differences in prevalence of an infectious disease in different races. Particular attention might be paid to symptomatic Syrian refugees, taking into epidemiological characteristics of TB disease and the density of immigrants in the place we live in.

\section{ETHICAL DECLARATIONS}

Ethics Committee Approval: For this study, ethical approval was obtained from the ethics committee of the Necmettin Erbakan Univercity School of Medicine with the decision number of 2020/2871.

Informed Consent: Because the study was designed retrospectively, no written informed consent form was obtained from patients.

\section{Referee Evaluation Process: Externally peer-reviewed.}

Conflict of Interest Statement: The authors have no conflicts of interest to declare.

Financial Disclosure: The authors declared that this study has received no financial support.

Author Contributions: All of the authors declare that they have all participated in the design, execution, and analysis of the paper, and that they have approved the final version.

\section{REFERENCES}

1. Mete Yesil A, Yalcin E, Ademhan Turhal D, et al. From Diagnosis to Treatment of Pediatric Tuberculosis: Ten Years Experience in a Single Institution. Clin Pediatr (Phila). 2020 May;59(4-5):476-482. doi: $10.1177 / 0009922820906488$.

2. Lamb GS, Starke JR. 2017. Tuberculosis in infants and children. Microbiol Spectrum 5(2):TNMI7-0037-2016. Review

3. World Health Organization. Global tuberculosis report 2020. file:///C:/ Users/acer/Downloads/9789240013131-eng\%20(1).pdf. Accessed December 26, 2020.

4. Türkiye'de Verem Savaşı 2019 Raporu. Sağlık Bakanlığı, Yayın No: 1168 Ankara 2020.https://hsgm.saglik.gov.tr/depo/birimler/tuberkuloz_db/ raporlar/Tu_rkiye_de_Verem_Savas_2019_Raporu_son_1.pdf. Accessed December 26, 2020. 
5. Ergönül Ö, Tülek N, Kayı I, Irmak H, Erdem O, Dara M. Profiling infectious diseases in Turkey after the influx of 3.5 million Syrian refugees. Clin Microbiol Infect. 2020 Mar;26(3):307-312. doi: 10.1016/j.cmi.2019.06.022.

6. Doganay $M$, Demiraslan H. Refugees of the Syrian Civil War: Impact on Reemerging Infections, Health Services, and Biosecurity in Turkey. Health Secur. 2016 Jul-Aug;14(4):220-5. doi: 10.1089/hs.2016.0054. Epub 2016 Jun 30. PMID: 27362427.

7. T.C. Sağlik Bakanliği. Tüberküloz Tanı ve Tedavi Rehberi: Sağlık Bakanlığı Yayın No: 1129, Ankara, Mayıs 2019. https://hsgm.saglik.gov.tr/depo/ birimler/tuberkuloz_db/haberler/Tuberkuloz_Tani_Ve_Tedavi_Rehberi_/ Tuberkuloz_Tani_ve_Tedavi_Rehberi.pdf Accessed December 26, 2020.

8. From Dallman, P.R., 1977. blood and blood forming tissues.In: rudolpg, A.M. (Ed), Pediatrics, sixteenth ed. Appleteon-Century-Crofts, Norwalk, CT.

9. Long SS, Vodzak J. Laboratory Manifestations of Infectious Diseases. In Long SS, Ficher M, Prober CG, editors. Principles and practice of pediatric infectious diseases. 5th ed. Philadelphia, PA: Elsevier; 2018. p.1447-1459.

10. Chiang SS, Starke JR. Mycobacterium tuberculosis. In: Long SS, Ficher M, Prober CG, editors. Principles and practice of pediatric infectious diseases. 5th ed. Philadelphia, PA: Elsevier; 2018. p. 790-806.

11. Bayhan Gi, Tanır G, Metin Ö, et al. Pediatric Tuberculosis in Turkey: A Review of 8-Years Period in a Tertiary Care Hospital. Turk J Pediatr. 2015 Sep-Oct;57(5):431-8.

12. Pekcan S, Tana Aslan A, Kiper N, et al. Multicentric analysis of childhood tuberculosis in Turkey. Turk J Pediatr. 2013 Mar-Apr;55(2):121-9

13. Liyew Ayalew M, Birhan Yigzaw W, Tigabu A, Gelaw Tarekegn B. Prevalence, Associated Risk Factors and Rifampicin Resistance Pattern of Pulmonary Tuberculosis Among Children at Debre Markos Referral Hospital, Northwest, Ethiopia. Infect Drug Resist. 2020 Oct 29;13:3863-3872.

14. Turel O, Kazanci S, Gonen I, Aydogmus C, Karaoglan E, Siraneci R. Paediatric Tuberculosis at a Referral Hospital in Istanbul: Analysis of 250 Cases. Biomed Res Int. 2016;2016:6896279.

15. Savaş N, Barutcu G, Yeniçeri A. Evaluation of purified protein derivates test at tuberculosis dispensary in Hatay, Turkey, applied to Turks and Syrian refugees (2012-2015). Cent Eur J Public Health. 2018 Dec;26(4):247-252.

16. Cano APG, Romaneli MTN, Pereira RM, Tresoldi AT. Tuberculosis in pediatric patıents: how has the diagnosıs been made?. Rev Paul Pediatr. 2017 Apr-Jun;35(2):165-170.

17. Peng SS, Chan PC, Chang YC, Shih TT. Computed tomography of children with pulmonary Mycobacterium tuberculosis infection. Journal of the Formosan Med Assoc 2011; 110: 744.

18. Dos Santos TCS, Setúbal S, Dos Santos AASMD, Boechat M, Cardoso CAA. Radiological aspects in computed tomography as determinants in the diagnosis of pulmonary tuberculosis in immunocompetent infants. Radiol Bras. 2019 Mar-Apr;52(2):71-77.

19. Hosten E, Mehta M, Andre E, Abu Rumman K, Van der Linden D. Tuberculosis contact-tracing among Syrian refugee populations: lessons from Jordan. Confl Health. 2018 Jul 16;12:25.

20. Cookson ST, Abaza H, Clarke KR, Burton A, Sabrah NA, Rumman KA, et al. Impact of and response to increased tuberculosis prevalence among Syrian refugees compared with Jordanian tuberculosis prevalence: case study of a tuberculosis public health strategy. Confl Health. 2015 May 18;9:18. 